\title{
ANALYSING A RIGHT-WING TEXT THROUGH HALLIDAY'S TRANSTIVITY SYSTEM AND CRITICAL DISCOURSE ANALYSIS
}

\begin{abstract}
In this paper, I attempt to present an example of following Halliday's grammatical system in analysing a text that can bear racial references. Doing so, the text analysis can be viewed from a critical discourse analysis perspective. The text chosen, titled "Europe Must Close Its Borders or be Swamped by Third World", published in 2009, exhibits a typical example of the political rhetoric used by far-right political parties represented by one of its leaders in Britain, Nick Griffin. My assumption is that every word, every verb, and every phrase used is carefully chosen to convey the intended agendas of the party to its prospect voters in a clever way, which achieves its maximum effect with little or no apparent violation to the press guidelines. I also believe that such a stirring text, as far as the paper is concerned, would benefit from the use of various types of verbs and phrases that should suffice the requirement of the analysis. The paper may be of good use to students interested in studying this system of analysis as it deeply goes into the details of the used text.
\end{abstract}

\section{Indexing terms/Keywords}

Systematic Functional Grammar, Text Analysis, Discourse Analysis, Policiticain Texts.

\section{Academic Discipline And Sub-Disciplines}

Linguistics, Applied Liinguistics

\section{TYPE (METHOD/APPROACH)}

Text Analysis

\section{INTRODUCTION}

According to Van Dijk (1993), for the discipline of discourse studies, racism expressed in text and talk offers a very relevant field of application, and provides insight into the relations between various text and talk structures. Furthermore, other various contexts that can reproduce racism, such as the mental, sociocultural, and political conditions, effects, or functions, all can be applied to the field. Van Dijk also clarifies how this discipline overlaps with linguistics as the study of racism and discourse reveals how ethnic biases and perspectives are expressed through various grammatical structures. In addition, he indicates that Political Science is mainly based upon discourse, such as in the parliamentary debates.

The analysis in this paper attempts to ideologically approach a right-wing text, which discusses the issue of immigration and asylum seekers in the UK by following Halliday's Transitivity Model. The text can be described as prejudiced, biased and unbalanced, a point the analysis aims to prove. The analysis in fact aims to identify and explain how ideology is constructed and presented through this article by looking at how Processes are represented through clauses in the text. According to Halliday and Matthiessen (2004: 31), in the tradition of SFL, the ideational is one of the main functions the language is used for in society. The analysis deals with the text as it appears in Appendix 1, not its published form on websites $^{1}$.

A recognized aspect of the right-wing is its utilization of language in legitimizing their way of dealing with the issue of immigration through the use of metaphors. According to Charteris-Black (2006), most phrases used in right-wing literature falls under one of two main categories, 'natural disaster' phrases and 'container' phrases. The paper therefore attempts to spot these metaphors, assess their significance in conveying intended meaning.

\section{HALLIDAY'S TRANSITIVITY}

Transitivity is a theoretical tool from Systematic Functional Grammar (SFG) which can be applied in the analysis of ideology in media. The existence of the transitivity model owes its current form in no small part to the work of Halliday (1985) whose theories set its bases. Halliday's work therefore would be the backbone of my paper.

Halliday's Transitivity is not the same traditional transitivity of merely distinguishing between verbs according to whether they have an object or not (Thomson, 2004). Instead, it refers to how meaning or Process is represented in the clause, it focuses on the propositional content of the message and not its purpose (Thomson,ibid.). Since language represents experiences from our external and internal worlds, it consists of various 'goings on', of doing, feeling, being, happening...etc, which are sorted out in the semantic system of the language and expressed through the grammar of the clause. Transitivity is concerned with the transmission of ideas, it is considered to fall within the realm of the ideational function of language. It specifies the different types of processes that are recognised in the language, and the structures by which they are expressed. Halliday's representation of processes is as follows:

The text was available at the $\begin{gathered}\text { National Party } \\ \text { News }\end{gathered}$ website, $\begin{gathered}\text { still available } \\ \text { at }\end{gathered}$
https://centurean2.wordpress.com,https://centurean2.wordpress.com/2009/07/10/europe-must-close-its-borders-or-be-swamped-by-third-
world-says-nick-griffin-mep/.

http://news.bbc.co.uk/2/hi/uk politics/8141069.stm 
The process itself - Participants in the process - Circumstances

The process in a clause is typically realised by verbal group, here is the point at which this and traditional transitivity may come together, but it can be regarded as what 'goings on' represented in the whole clause. This term of process is too general to explain, there are different specific types of process that are built in the semantics of English, and SFG distinguishes carefully between them.

\section{Halliday's Classification of the Processes}

Material Processes (processes of doing)

Mental Processes (processes of sensing, feeling, thinking, perceiving)

Relational Processes (processes of being or having)

Verbal Processes (processes of saying or meaning)

Behavioral processes (processes of becoming)

Existential (processes of happening)

The Participants are the entities involved in the process, the doers or done to, they are mostly human but they can be inanimate.

The particular kinds of participant role labeled differently according to the processes they are associated with:

Material Process: (Actor and/or Goal) sometimes this process-with certain verbs- involves three participants, with the third called Beneficiary.

According to Thompson (2004) Beneficiary can occur with all process types except Existential. It is specially associated with Mental and Material

\section{Mental Processes: (Sensor and Phenomenon)}

Relational Processes: (Carrier and Attribute / Token and Value)

Verbal Processes: (Sayer) in some cases there may be Receiver, Target and/or Verbiage.

\section{Behavioural process: (Behaver)}

\section{Existential processes: (Existent)}

The background details of place, time, manner, etc... against which those processes and participants go on is represented as Circumstances that are typically realised by adverbial groups or prepositional phrases.

However, as Alameda-Hernández (2008) puts it, a functional analysis is not simply a question of labeling (i.e. identifying the types of processes, participants or circumstances), it implies an act of reasoning and interpretation as well.

\section{THE ANALYSIS of the TEXT}

The analysis of the processes occur through clauses on Nick Griffin, leader of the British National Party (BNP) and recently a Member of the European Parliament. The article in question quotes some of his controversial sayings. The analysis is constructed predominantly with verbal processes, says, said, told threefold in each of the following order; Quoted-Process-Sayer, Quoted-Sayer-Process, Sayer-Process-Reported, and only once in Sayer-Process-Quoted order when the quotation 'and they can go back to Libya' comes after the reported clause in line (18), (see appendix 1). Following the conventional rule, the sayers in Quoted-Process-Sayer order are in full nominal groups-(see figure 1 in Appendix 2). In line (9) the process and sayer 'say the Italians' occur within the quotation rather than at the beginning or the end. For the other orderings, the sayers are assigned with either full names or pronouns; actually there is no speaker other than him (Mr. Griffin). Throughout these verbal processes, the participant role of Receiver occurs only once in Quoted-Sayer-Process order (the BBC) - See figure (2), unless if we consider the Receiver of the nominalized verb speaking in line (21) which is (BNP News). Both receivers are metaphorically addressed since the Sayer speaks to people work in these two stations to report his message to the Target audience.

Since Mr. Griffin represents the higher authority in this text, in comparison the immigrants are seen as inferiors hence do not have authority at all, their saying is not of interest to the writer and therefore largely ignored. Such a pattern, in which none of the verbal processes considers them as Sayers, there is only one more participant 'the Italians' besides Nick Griffin who is assigned with the verbal process 'say'. This later participant again represents the higher authority as it supports the former. However, these verbal expressions of their demands endow them with greater power.

In fact, the text is based on Mr. Griffin's speech, in addition to the previous verbal processes. The rest of the text consists of quotations without indicating either the process or sayer as it is clear enough who says that - see figure (5). Therefore, all the other types of process and participant that will be analysed are contained within the quoted and reported clauses.

The most dominant type of processes throughout the text is the Material Process, in which the immigrants are mostly assigned the participant role of Goal for the actions taken by The European Parliament, which in its turn functions as Actor in most situations. Even when immigrants are assigned the participant role of Actor, their actions do not have an effect on 
the Parliament, they are only ascribed to the journey that cross the sea rather than human beings; cross and undertake do not affect people as goals, what it actually implies is that actions do not have a direct effect or harm on the opposing side.

In other words, the immigrants are mostly represented as objects or passive entities who are affected by decisions of the Parliament, (if some boats were sunk, could be given a life raft, they are convinced, they will be allowed in, they will under no circumstances be allowed in). The process sink which appears four times through the text including The European Parliament as Actor shows the predetermination of the authority to simply drown human lives, expressing that in relation to the only way, should and need which emphasize this position. In fact, the level of modality assigned to both sides through certain modal auxiliaries can signify clearly their two opposite conditions, to stop and sink the immigrants and their boats is a need which they must, should and has to fulfill. Considering the poor condition of the immigrants, they could be given a life raft so they can go back. Another indication is in lines $(22-23)$, which can simplify the matter of having lives to be drowned is to give a possible justification in the behavioral process drown that is semantically related to a certain extent with their action sink, constructed with every year and in their attempts circumstances that can create the sense of its regularity and commonness (See figures 6 \&12).

The deliberate choices of certain material processes, with which the participant role of The European Parliament is Actor, show their great opposition to immigration and immigrants, (close, set up, stop, going to stop, prevent, stopped) the process close in particular is tripled by Nick Griffin, once in the headline with high modality Must, and it is mentioned again as the first sentence of the text. Then as quoted with different tone of modality using has to and a circumstance sooner or later emphasizing the immediacy of their intentions (see line 19). What may clarify the authority's behavior towards those immigrants, as they are referred to by the speaker, is the choice of the intensified behavioral process get very tough of which The EU is the proper Behaver. To my best understanding, although get tough can be considered Relational/Attributive Process, the accompanying of with them modifies the meaning of the process as treat them in a tough manner, which is usually labeled as Behavioral. According to the analysis, the set of behavioral processes involves the immigrants as Behavers, through which their attempts are represented to reach the opposing lands, (got to, get over, coming over, get to, go back, entering) (See figure 12).

The mental process need which appeared twice in the text involves only the higher authorities to be their participants with senser roles. And when the opposite participant is involved in such process as senser, it is to submit 'get' to the phenomenon expressed by that authority 'the message'. Otherwise, the immigrants are passively assigned with the Senser role in 'are convinced'. (See figure 11)

When defining each process, I refer to many participants as implicit since they are sometimes dependent to a preceding clause or process, or impeded as referred to by Thompson (2004). The same Theme is shared by more than one clause if it is possible to say so - like in the headline Europe is a participant for two processes; must close and be swamped. Other examples are in line (9) set up and help in a dependent clause, and going to stop and stop in line (11), which occur in a clause that modify or explain something about the only measure. I define the latest as identifier of the relational process is. In some other occasions, the participants I define in this text are included in other processes, I analyse those processes in different figures according to their types. (See figure 7)

Like the mental processes, the relational and existential processes are less frequent in this text if compared with the Material, Verbal or Behavioral ones. The relational seems to happen as its nature which is explained by Bloor \& Bloor (1995); complicated, frequently impossible and difficult to classify precisely. Here I shall consider was, is and means as relational processes involving Token and Value as their participant roles - see figures (7 \& 8). According to my understanding of the existential process I think 'anything which is there' can be classified as existential grammatically realised by a copular verb is and an empty subject there, although it is in different order than that which is mentioned by Bloor \& Bloor (ibid.). According to Bloor \& Bloor, there is usually placed at the beginning of the sentence, e.g.(there are measures), what I'm suggesting here is that we will have the same if the sentence is rewritten in its regular occurrence, anything which is there or there is anything, bearing in mind that anything is further mentioned in full by the speaker.

Though I find it clear enough as interpreted in the previous paragraph, when following the example ${ }^{2}$ by Bloor \& Bloor (ibid: 125), which shows how related relational and existential processes may be, I tend to think that in this clause the process could be relational as well. Treating there as circumstance, we will have the circumstantial type ${ }^{3}$ of the relational process in which anything and there are involved as participants assigned with carrier and attribute roles respectively.

The semantic load that is carried by some adverbials or modal adjuncts produced by Nick Griffin in the text has been well employed to support the decisiveness of The_European Parliament's position. For example, sooner or later, used twice, besides under no circumstances, frankly, simply, actually, very clearly and ultimately that express their urgent desire to achieve their firm decision. According to Halliday (2004), circumstances can occur freely in all types of process, but there is some special interpretation of some combinations. For example, circumstances of Matter are fairly common with Material and Verbal, and it can rarely occur with certain Behavioral clauses. In fact, through the clauses of this text some place, means and temporal adjuncts accompany the material processes; before they got to shore, before they reach, in their rickety unseaworthy boats and every year. Other types of circumstances with other processes are presented in Appendix (2).

\footnotetext{
2 Ten of us were in the party' where ten of us would function as Carrier and in the party as Attribute.

3 This circumstantial type is referred to as locational by Christopher S. Butler (2003:221)
} 
Speaking on behalf of the parliament, the pattern used by Mr. Griffin in lines (14-15-16), where he anticipates what others' attitudes might be, directly followed by responses such as we'll support and we'll oppose. This can highly signify their rejection to any other solution than the one and only they insist on.

The language encoded by the speaker constructs the immigrants metaphorically as fluid or liquid that will swamp Europe. According to Charteris-Black (2006), the verb swamp in relation to immigration, first used by Enoch Powell, then by Margaret Thatcher, evokes strong emotions and creates the sense that immigration is excessive, hence appeals to the ideological political argument that certain procedures must be taken to stop it. The participant role of Third World as Actor and Europe as Goal has its effect in picturing Europe as a victim in spite of its recognized superior position. I tend to think that this Third World participant again represents people as objects that have no relation to life, what might be seen as dehumanization.

Charteris-Black (ibid.) also classifies the metaphors that are related to immigration as metaphors of natural disasterpredominantly the behavior of fluids - and the container metaphors. He indicates that the natural disaster metaphors predominate in the political statements of the far-right wing British National Party. He clarifies why such metaphors occur by referring to the importance of the sea in the British cultural and its historical identity. Another reason probably is because many immigrants arrive in Britain by water, he suggests that such metaphors are preferred because liquids, tides or waves move around by their nature hence the change which will occur, whether politically or socially, will be out of control. Since liquid metaphor evokes deeper cultural and historical experience related to invasion and control over the sea as the cause of earlier national glory. It has been used frequently to attribute immigrants with invaders, the term invasion which is equated with immigration arouses fear and threat so it properly can achieve its purpose. In this text, the invaders' boats are involved in the material process sink with the participant role as Goal that must be sunk by authorities. Invasion is likewise mentioned in the previous clause also attributed with mass to be a mass immigration invasion, syntactically though. According to my interpretation, a mass immigration invasion seems to be the Behaver participant represented in stopped process, I believe since there is an instigation by The European Parliament to stop mass immigration to Europe. It is likely to be its implicit Actor participant on a semantic level. Although the fluid or liquid processes might be realized as Behavioral when tackling the dynamism level that is implied with such actions, following the rule of thumb that indicates that behavioral process are always intransitive verbs, i.e. do not have objects or goals, I classify some of them under the Material Process category since Goals are there to be involved under such processes.

A group of processes have been nominalised (speaking-carrying-dying-entering-coming up-doing-bringing-coming), implicitly, again Mr. Griffin is assigned with the participant role of Sayer in two verbal processes, and immigrants are represented as Goal participants in three material processes. Though usually interpreted as behavioral process, reckoning on Halliday and Crombie's definitions of transitivity in the example ${ }^{4}$ that is explained in a paper by Laskewicz (2008), I shall consider the process dying as material since if we think of the implicit Actor or the cause in this clause 'dying on the way' it is probable according to the context to be the sea or their rickety unseaworthy boats. And if we have the sentence rewritten we will have a material process such as Their rickety unseaworthy boats drown them, hence the immigrants are assigned the Goal participant role.

It can be seen from the analysis of this text that the types of processes have shown that the kind of actions The European Parliament is most frequently involved in are material and verbal. Next in frequency of their actions are represented through the behavioral processes in this corpus. Going to the realm of mental processes, which usually follow the material processes in the proportion of occurrence, they are constructed only twice with Senser participants. However, from the analysis of the roles that are assigned to them as participants, it has been shown that they are predominantly assigned with Actor and Sayer roles, then only twice as Sensers and Behavers in each process. Consequently, the immigrants, according to the material processes, are always involved in and assigned with the participant role of Goal. But they are predominantly assigned with Behaver roles as it is mentioned above, and they are also equally proportioned with the authority in the Mental Processes as Sensers. (See Figure 14)

Generally speaking, the process types found in the text are mostly Material Processes followed by Verbal and Behavioral at 12 cases each as shown in the following graph.

\footnotetext{
${ }^{4} \mathrm{He}$ died of Polio. Crombie would define this sentence as falling into type 1: Dynamic predicates. Polio takes the causative semantic role of Force, whereas he becomes the Patient. The sentence could be rewritten in the following way: Polio killed him. In this sense, Halliday would define the sentence as being a material process and an event, in which polio is the actor and he is the goal.
} 

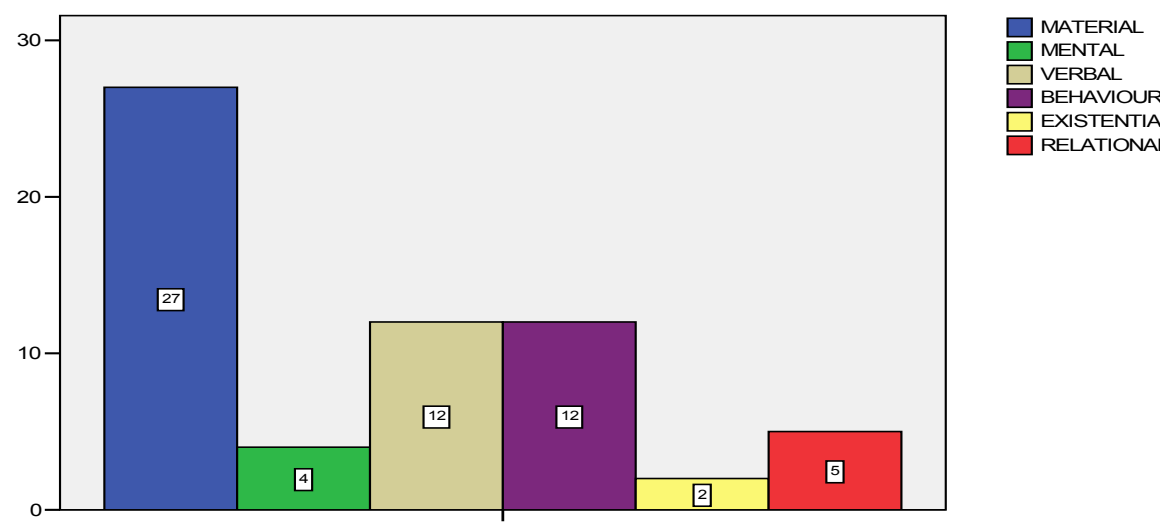

1. Results of the types of processes found in the text analysis

\section{CONCLUSION}

Despite all racial concerns, the text seems somehow balanced when compared with other materials that use far more aggressive metaphors to represent immigrants, e.g. as animals. All things considered, the text can be seen as tough rather than racist since it disregards the dignity of human lives. Since uncontrolled immigration brings undesired changes to societies-political, social and religious, as well as putting more pressure on basic services such as education and hospitals, people would naturally defend their identity and resources and they have the right to do so.

\section{REFERENCES}

[1] Alameda-Hernández, A. .2008. 'SFL and CDA: Contributions of the Analysis of the Transitivity System in the Study of the Discursive Construction of National Identity (Case study: Gibraltar)', In The Linguistic Journal , 3(3), 160 - 175

[2] Bloor, T., \& Bloor, M. .1995. The functional analysis of English: A Hallidayan approach, London: Arnold.

[3] Butler, C. .2003. Structure and Function: A Guide to Three Major Structural-Functional Theories: Part 1: Approaches to the Simplex Clause, John Benjamins

[4] Charteris -B lack, J. .2006. 'Britain as a container: immigration metaphors in the 2005 election Campaign', In Discourse and Society, (17) 5, $583-608$.

[5] Halliday, M.A.K. \& Matthiessen, C. .1985. An Introduction to Functional Grammar. London: Arnold.

[6] Halliday, M.A.K. \& Matthiessen, C. .2004. An Introduction to Functional Grammar. London: Arnold.

[7] Laskewic, Z. .2008. Paradigm Shift in Language: Transitivity in Haliiday and Crombie, Belgium: Nightshades Press.

[8] Thompson, G. .2004. Introducing Functional Grammar, London: Arnold.

[9] Van Dijk, T. A .1993. 'Analyzing racism through discourse analysis. Some methodological reflections', In: J. Stanfield (Ed.), Race and ethnicity in Research Methods. (pp. 92-134). Newbury Park, CA: Sage. Available online athttp://www.discourses.org/OldArticles/Analyzing\%20racism\%20through\%20discourse\%20analysis.pdf 
APPENDICES

(1)

Europe Must Close Its Borders or be Swamped by Third World, Says Nick Griffin MEP

\begin{tabular}{|l|c|c|}
\hline \multicolumn{1}{|c|}{ Quoted (Projected) } & Process & Sayer \\
\hline $\begin{array}{l}\text { Europe Must Close Its Borders or be Swamped by Third } \\
\text { World }\end{array}$ & says & Nick Griffin MEP \\
\hline $\begin{array}{l}\text { Europe must close its borders or it will be swamped by } \\
\text { the Third World }\end{array}$ & said & $\begin{array}{l}\text { British National Party leader and Member of } \\
\text { the European Parliament Nick Griffin. }\end{array}$ \\
\hline $\begin{array}{l}\text { If there are measures to set up some kind of force or to } \\
\text { help, set up a force which actually blocks the } \\
\text { Mediterranean, then we'd support that. }\end{array}$ & say & \\
\hline
\end{tabular}

\section{Figure (1) Verbal Processes/Quoted-Process-Sayer}

Europe must close its borders or it will be swamped by the Third World, said British National Party leader and Member of the European Parliament Nick Griffin.

Speaking on a Brussels-based BBC show The Record Europe, Mr. Griffin said the only way to make sure that the mass immigration invasion stopped was to sink some of the invaders' boats before they got to shore.

"The EU should sink boats carrying illegal immigrants to prevent them entering Europe," Mr. Griffin told the BBC.

"If there are measures to set up some kind of force or to help, say the Italians, set up a force which actually blocks the Mediterranean, then we'd support that".

"But the only measure, sooner or later, which is going to stop immigration and stop large numbers of sub-Saharan Africans dying on the way to get over here is to get very tough with those coming over. Frankly, they need to sink several of those boats," he said.

"Anyone coming up with measures like that we'll support but anything which is there as an 'oh, we need to do something about it' but in the end doing something about it means bringing them into Europe, we will oppose."

Mr. Griffin said that if some boats were sunk before they reached the southern European coast, the people on the boats could be given a life raft "and they can go back to Libya."

"But Europe has sooner or later to close its borders or it's simply going to be swamped by the Third World."

Speaking to BNP News after the interview, Mr. Griffin said the move would actually save lives. "Thousands of Africans drown every year in their attempts to cross the Mediterranean in their rickety unseaworthy boats," he said. "They undertake this hazardous journey because they are convinced that if they get to Europe, they will be allowed in.

"If they get the message very clearly that they will under no circumstances be allowed in, they will stop coming. Ultimately, it is the only solution to this ongoing problem."

http://centurean2.wordpress.com/2009/07/10/europe-must-close-its-borders-or-be-swamped-by-third-world-says-nickgriffin-mep/

(2)

\begin{tabular}{|l|c|c|c|}
\hline \multicolumn{1}{|c|}{ Quoted (Projected) } & Sayer & Process & Reciver \\
\hline $\begin{array}{l}\text { The EU should sink boats carrying illegal } \\
\text { immigrants to prevent them entering Europe }\end{array}$ & Mr Griffin & told & the BBC \\
\hline $\begin{array}{l}\text { But the only measure, sooner or later, which is } \\
\text { going to stop immigration and stop large } \\
\text { numbers of sub-Saharan Africans dying on the } \\
\text { way to get over here is to get very tough with } \\
\text { those coming over. Frankly, they need to sink } \\
\text { several of those boats }\end{array}$ & he & said & \\
\hline $\begin{array}{l}\text { Thousands of Africans drown every year in their } \\
\text { attempts to cross the Mediterranean in their } \\
\text { rickety unseaworthy boats }\end{array}$ & he & said & \\
\hline
\end{tabular}

Figure (2) Verbal Processes/Quoted -Sayer-Process-Receiver 


\begin{tabular}{|l|c|l|}
\hline Sayer & Process & \multicolumn{1}{|c|}{ Reported (projected) } \\
\hline Mr Griffin & said & $\begin{array}{l}\text { the only way to make sure that the mass immigration invasion } \\
\text { stopped was to sink some of the invaders' boats before they got to } \\
\text { shore. }\end{array}$ \\
\hline Mr Griffin & said & $\begin{array}{l}\text { that if some boats were sunk before they reached the southern } \\
\text { European coast, the people on the boats could be given a life raft }\end{array}$ \\
\hline Mr Griffin & said & the move would actually save lives. \\
\hline
\end{tabular}

Figure (3) Verbal Processes/ Sayer- Process-Reported

\begin{tabular}{|c|c|l|}
\hline Sayer & Process & \multicolumn{1}{c|}{ Quoted (Projected) } \\
\hline Mr Griffin & said & and they can go back to Libya \\
\hline
\end{tabular}

Figure (4) Verbal Processes/ Sayer- Process-Quoted

\begin{tabular}{|l|}
\hline \multicolumn{1}{|c|}{ Quotations (Projections) } \\
\hline "Anyone coming up with measures like that we'll support but anything which is there as an \\
'oh, we need to do something about it' but in the end doing something about it means bringing \\
them into Europe, we will oppose." \\
\hline "But Europe has sooner or later to close its borders or it's simply going to be swamped by the \\
Third World." \\
\hline "They undertake this hazardous journey because they are convinced that if they get to \\
Europe, they will be allowed in. \\
"If they get the message very clearly that they will under no circumstances be allowed in, they \\
will stop coming. Ultimately, it is the only solution to this ongoing problem."
\end{tabular}

Figure (5) Quotations

\begin{tabular}{|c|c|c|c|}
\hline Actor & Process & Goal & Circumstance \\
\hline Europe & must close & its boarders & \\
\hline the Third World & be swamped & implicit (Europe) & \\
\hline implicit (authorities) & stopped & $\begin{array}{l}\text { the mass immigration } \\
\text { invasion }\end{array}$ & \\
\hline the Third World & will be swamped & it (Europe) & - \\
\hline implicit (authorities) & sink & $\begin{array}{l}\text { some of the invaders' } \\
\text { boats }\end{array}$ & $\begin{array}{l}\text { before they got to shore } \\
\text { (Time sequence) }\end{array}$ \\
\hline The EU & should sink & boats & \\
\hline implicit (authorities) & prevent & them & \\
\hline implicit & set up & some kind of force & \\
\hline implicit & set up & a force & \\
\hline implicit (force) & blocks & The Mediterranean & \\
\hline we & would support & that & \\
\hline implicit (the only measure) & going to stop & immigration & \\
\hline implicit (the only measure) & stop & $\begin{array}{l}\text { large numbers of sub- } \\
\text { Saharan Africans }\end{array}$ & \\
\hline we (authorities) & 'll support & $\begin{array}{l}\text { implicit (Anyone coming } \\
\text { up with measures like } \\
\text { that) }\end{array}$ & \\
\hline
\end{tabular}


Journal of Advances in Linguistics

\begin{tabular}{|c|c|c|c|}
\hline Implicit (authorities) & were sunk & some boats & $\begin{array}{l}\text { before they reached the } \\
\text { southern European coast } \\
\text { (Time sequence) }\end{array}$ \\
\hline Europe & has to close & its borders & sooner or later (extent/time) \\
\hline The Third World & is going to be swamped & it ( Europe ) & simply (manner) \\
\hline move & would save & lives & \\
\hline implicit (immigrants) & cross & the Mediterranean & $\begin{array}{l}\text { in their rickety unseaworthy } \\
\text { boats (means) }\end{array}$ \\
\hline they & undertake & this hazardous journey & \\
\hline implicit & will be allowed in & they & \\
\hline implicit & will be allowed in & they & $\begin{array}{l}\text { under no circumstances } \\
\text { (manner) }\end{array}$ \\
\hline
\end{tabular}

Figure (6) Material Processes

\begin{tabular}{|l|c|c|c|}
\hline $\begin{array}{c}\text { Participant } \\
\text { (Carrier) }\end{array}$ & process & $\begin{array}{l}\text { Empty subject ( } \\
\text { Attribute) }\end{array}$ & Circumstance \\
\hline it & is & the only solution & to this ongoing problem (angle) \\
\hline
\end{tabular}

Figure(7) Relational Process: Identifying Process

\begin{tabular}{|l|c|c|}
\hline \multicolumn{1}{|c|}{ Participant (Existent ) } & $\begin{array}{l}\text { proce } \\
\text { ss }\end{array}$ & Empty subject \\
\hline $\begin{array}{l}\text { anything (as an 'oh, we need to do something about it' but in the } \\
\text { end doing something about it means bringing them into Europe) }\end{array}$ & is & there \\
\hline
\end{tabular}

Figure(8) Relational Process: Attributive Process

\begin{tabular}{|c|c|c|}
\hline Empty subject & $\begin{array}{c}\text { Process ( copular } \\
\text { verb) }\end{array}$ & Participant (Existent ) \\
\hline there & are & measures \\
\hline
\end{tabular}

Figure (9) Existential Process/ Existent - Process- Empty subject

\begin{tabular}{|c|c|c|c|}
\hline Senser & Process & Phenomenon & Circumstance \\
\hline They(authorities) & need & to sink several of those boats & \\
\hline we(authorities) & need & to do something & $\begin{array}{l}\text { about it } \\
\text { (matter) }\end{array}$ \\
\hline They(immigrants) & get & the message & $\begin{array}{l}\text { very clearly } \\
\text { (manner) }\end{array}$ \\
\hline they (immigrants) & $\begin{array}{l}\text { are } \\
\text { convinced }\end{array}$ & $\begin{array}{l}\text { that if they get to Europe, } \\
\text { they will be allowed in }\end{array}$ & \\
\hline
\end{tabular}

Figure (10) Existential Process/ Empty subject - Process- Existent 
I SSN $2348-3004$

Volume $6 \mathrm{Number} 3$

Journal of Advances in Linguistics

\begin{tabular}{|l|c|l|}
\hline \multicolumn{1}{|c|}{ Participant (identified- token) } & Process & \multicolumn{1}{|c|}{ Participant (identifier-value) } \\
\hline $\begin{array}{l}\text { the only way to make sure that the } \\
\text { mass immigration invasion stopped }\end{array}$ & was & $\begin{array}{l}\text { to sink some of the invaders' boats before } \\
\text { they got to shore }\end{array}$ \\
\hline the only measure & is & to get very tough with those coming over \\
\hline there & is & anything \\
\hline doing something about it & means & bringing them into Europe \\
\hline
\end{tabular}

Figure (11) Mental Processes

\begin{tabular}{|c|c|c|c|c|}
\hline Behaver & Process & Range & \multicolumn{2}{|l|}{ Circumstance } \\
\hline we (authorities) & will oppose & & & \\
\hline implicit (authorities) & \begin{tabular}{l|l} 
es) & get tough
\end{tabular} & & \multicolumn{2}{|c|}{ with those coming over (accompaniment) } \\
\hline $\begin{array}{l}\text { implicit } \\
\text { (authorities) }\end{array}$ & help & & & \\
\hline $\begin{array}{l}\text { implicit } \\
\text { (authorities) }\end{array}$ & make sure & & & \\
\hline they (immigrants) & got to & shore & & \\
\hline $\begin{array}{l}\text { implicit } \\
\text { (immigrants) }\end{array}$ & get over & & here (location) & \\
\hline they (immigrants) & reached & $\begin{array}{l}\text { the southern European } \\
\text { coast }\end{array}$ & & \\
\hline they (immigrants) & can go back & & to Libya (location) & \\
\hline $\begin{array}{l}\text { thousands of } \\
\text { Africans }\end{array}$ & drown & & every year in their attempts & (time /contingency) \\
\hline they (immigrants) & will stop & coming & & \\
\hline \multicolumn{5}{|c|}{ Figure(12)Behavioral Processes } \\
\hline Process & Type & Participant & Participant & Circumstance \\
\hline speaking & Verbal & Sayer - Mr Griffin & & $\begin{array}{l}\text { on a Brussels-based BBC show } \\
\text { The Record Europe (location) }\end{array}$ \\
\hline carrying & Material & Actor- boats & Goal-illigal immigrant & \\
\hline entering & Behavioral & & & \\
\hline dying & Behavioral & . & & on the way (location) \\
\hline coming up & Behavioral & $\begin{array}{l}\text { Behaver- Anyone } \\
\text { (whom Mr.Griffin is } \\
\text { addressing for help) }\end{array}$ & & \\
\hline doing & Material & $\begin{array}{l}\text { Actor- implied (Anyone } \\
\text {;whom Mr.Griffin is } \\
\text { addressing for help) }\end{array}$ & Goal- something & about it (matter) \\
\hline bringing & Material & $\begin{array}{l}\text { Actor- implied (Anyone } \\
\text {;whom Mr.Griffin is } \\
\text { addressing for help) }\end{array}$ & $\begin{array}{l}\text { Goal-them (illegal } \\
\text { immigrant) }\end{array}$ & into Europe (location) \\
\hline speaking & Verbal & Sayer - Mr Griffin & Receiver- BNP News & $\begin{array}{l}\text { after the interview (time } \\
\text { sequence) }\end{array}$ \\
\hline
\end{tabular}


ISSN $2348-3004$

Volume $6 \mathrm{Number} 3$

\begin{tabular}{|c|c|c|}
\hline PARTICIPANT ROLE & \multicolumn{2}{|c|}{ OCCURANCE } \\
\hline & Authorities & Immigrants \\
\hline Actor & 11 & 5 \\
\hline Goal & 4 & 10 \\
\hline Sayer & 12 & 0 \\
\hline Senser & 2 & 2 \\
\hline Behaver & 4 & 6 \\
\hline
\end{tabular}

Figure (14) Participant roles assigned to both Authorities and Immigrants in the text 